\title{
THE CHARACTERISTICS AND SUITABILITY OF THE SOILS OF SOME MAJOR COCOA GROWING AREAS OF NIGERIA: ETUNG LGA OF CROSS RIVER.
}

\author{
${ }^{*}$ Ajiboye' G. A., Jaiyeoba" J. O., Olaniyan ${ }^{3}$ J. O. And Olaiya', A. 0 \\ ${ }^{1}$ Department of Soil Science and Land Management, College of plant Science and Crop \\ Production,Federal University of Agriculture Abeokuta, Abeokuta Ogun State Nigeria \\ ${ }^{2}$ Nasarawa State University \\ ${ }^{3}$ Agronomy Department, Faculty of Agriculture, \\ University of Ilorin.
}

Email: godwinajiboye@gmail.com

\begin{abstract}
The soils of the major cocoa growing district of Etung Local Government Area of Cross River State were surveyed using a flexible grid method to assess the suitability of these soils for cocoa production. This study was carried out as part of efforts to revitalize cocoa production in Nigeria. Both the linear and square root parametric models of suitability assessment were used for the evaluation exercise. From the computed values of the current index productivity (1.80 12.75), all the mapping units delineated from the exercise were currently not suitable (N2) for cocoa production. The limiting factors identified include high rainfall $>2500 \mathrm{~mm}$ annually) and relative humidity (65.5\% - 85\%), low fertility ( $N, P, K, C a, M g$ ) resulting from nutrient leaching, low pH (3.45 4.90 in $\mathrm{KCl})$ and cation exchange capacity $\left(1.6710 .75 \mathrm{cmol} \mathrm{kg}^{-1}\right)$, and low to toxic concentrations of $\mathrm{Fe}, \mathrm{Mn}, \mathrm{Cu}$ and $\mathrm{B}$ in the soils. However, the values of potential productivity index (13.41 - 45) suggested that most of the mapping units will be marginally suitable (S3) for cocoa production with adequate application of appropriate fertilizers and suitable soil management practices. This will require a carefully designed fertilizer trial to ascertain the optima fertilizer level, fertilizer types and application methods.
\end{abstract}

Key words: Land suitability, Cocoa production, Soil fertility, Soil management and Etung LGA.

\section{INTRODUCTION}

Since the discovery of crude oil in Nigeria in the late sixties, there has been a drastic shift from agriculture which was the main hub of Nigeria economy to crude oil production. Since the oil boom, agriculture, which was the major contributor to the gross domestic product (GDP) of the country (Jimoh, 2005), has been relegated to the background. Nigeria dependence on oil revenue as the major source of income to the nation has been described as unhealthy economy because of the prevailing agitation for a cleaner source of energy than fossil fuel. As such, the government is now considering the revitalization of the agricultural sector of the economy. Some of the major tree 
crops that had contributed immensely to the external earnings of the country in the past included oil palm, rubber, cocoa, coffee etc. The focus of the government is to revitalize the production of some of these crops, especially cocoa and oil palm.

Due to years of neglect, there has not been major improvement in cocoa production technology. This has brought down the ranking of Nigeria as the world's fourth largest producer of cocoa. Statistical record in 2005/2006 production season indicated that Nigeria produced 170,000 tons of cocoa which accounted for about $5 \%$ of global production (ICCO, 2006).

If agriculture is going to contribute immensely to the Gross Domestic Product of the country, the present contribution of cocoa (about 30\%) to Nigeria's Agricultural GDP must be doubled within the next few years.

Cocoa is produced by small-scale farmers on small farms ranging in size between 15 hectares and relying mainly on family labour (70\%), hired labour (20\%) and caretaker labour (10\%) (Hamzat etal., 2006).

Export earnings from cocoa worth more than one hundred and twenty billion Naira annually. Also, there are over five million people employed in Nigerian Cocoa Industry ranging from peasant farmers to processors and exporters driving its value chain (Afolayan et al., 2006).Apart from direct export earnings, bye-product from cocoa processing have been identified as potential source of ingredient for several agro-inputs including livestock feeds (Adeyina et al., 2010). Cocoa is one of the major sources of revenue for about fourteen producing states of Nigeria (Hamzat et al., 2006). However, the production of this important export crop in Nigeria has suffered a decline in the recent years as a result of a number of factors such as low yield arising from old and poor planting material; depletion of humid rainforest and decline in soil fertility; lack of good agricultural practices in the management of Cocoa plantation (Iremiren et al., 2012) and the prevalence of malaria among farmers which has been reported to account for about $3 \%$ loss in the GDP from the agricultural sector (Jimoh, 2005). There is an urgent need for improvement in all the series of activities from site selection to primary processing that will ensure sustainable Cocoa farming in Nigeria.

As a first step towards the revitalization of cocoa production in Nigeria, it is the objective of this study to re-evaluate the suitability of the soils of Etung Local Government Area (LGA) which is one of the major cocoa producing hubs and to suggest possible management practices that could ensure high productivity and sustainability of cocoa production in this LGA.

\section{THE MATERIALS AND METHODS}

Based on the cocoa production survey report carried out in 2005- 2007 (Iremiren et al., 2008), Etung LGA(Cross River State), which was ranked as the highest producer of cocoa in the country was selected for this study.

A total of 37,000 hectares of land were selected from the LGA for this study. The selected area were several villages including Ajassor village, Ajassor Mission, Okoroba, Ogaranjor plantation, Ekwatai, part of Bikpare, Effraya, Three corner, Ekimaya, Last Motor, CRIN station, Etomi, Agboti, Agbokim, 
Abonita and Bikpare.

The flexible grid survey method was used for sampling. At each sampling point, samples were collected from the surface to a depth of $90 \mathrm{~cm}$ at intervals of $15 \mathrm{~cm}$. The samples collected were described morphologically (colour, texture, consistency, stoniness, root abundance, colour mottles etc.) in-situ. Similarities in the above mention properties were used in locating the mapping units. Eight mapping units were delineated at the end of the survey exercise and a profile pit was dug in each of the mapping units. The profiles were located at Ogaranjor plantation (between Ajassor Mission and CRIN), Three Corner, Ajassor Village, Okoroba road, Effraya, ADC plantation, Agbokim Camp 2, Bikpare village and Effraya town. Soil samples were taken from the pedogenic horizons of these profile pits. The collected samples were air dried and passed through $2 \mathrm{~mm}$ sieve before the samples were used for laboratory analyses.

The laboratory analyses carried out included the particle size distribution using the hydrometer method (Day, 1982), the pH was determined with glass electrode $\mathrm{pH}$ meter in soil: water and soil: $\mathrm{KCl}$ media, each at ratio 1: 1 (Maclean, 1982), organic carbon by wet oxidation method (Nelson and Sommers, 1975), total nitrogen by Kjeldahl method, available P was extracted with Bray-1 (Anderson and Igram, 1993) and $P$ concentration in the extract was determined using the vanadomolybdate blue method (Murphy and Riley, 1962). Total exchangeable acidity $\left(\mathrm{H}^{+}+\mathrm{Al}^{3+}\right)$ was extracted with molar $\mathrm{KCl}$ and determined by titration method (FAO, 2007). Exchangeable cations (calcium, magnesium, potassium and sodium) were extracted with neutral normal sodium acetate $\left(\mathrm{NH}_{4} \mathrm{OAc}\right.$ at $\mathrm{pH}$ 7.0). Calcium and magnesium in the ammonium acetate extract were determined by atomic absorption spectrophotometry, while potassium and sodium were determined by flame photometry. The effective cation Exchange capacity (ECEC) was determined by the summation of the exchangeable bases ( $\mathrm{Ca}, \mathrm{Mg}, \mathrm{Na}$ and $\mathrm{K}$ ) and exchangeable acidity. Available micronutrients ( $\mathrm{Zn}, \mathrm{Cu}, \mathrm{Fe}$ and $\mathrm{Mn}$ ) were extracted with $0.04 \mathrm{M}$ EDTA and their concentrations determined by AAS, while boron was extracted using the hot water method (FAO, 2007).

The saturated hydraulic conductivity (Ks) was determined by constant head soil core method of Reynolds (1993) by transposed Darcy's equation for vertical flow of liquid:

$$
K s=\frac{Q W \times d}{h \times A \times t}
$$

Where $\mathrm{Qw}$ is the volume of water $\left(\mathrm{cm}^{3}\right)$ that flowed through a cross-sectional area $\mathrm{A}\left(\mathrm{cm}^{2}\right)$ in time $(\mathrm{t})$, and $h$ is the hydraulic head difference $(\mathrm{cm})$ imposed across the sample length $\mathrm{d}(\mathrm{cm})$.

The parametric linear model of land evaluation (Uddoh, 2008; Ajiboye et al., 2011) was used for the quantitative land evaluation. Each pedon was assigned to a suitability class by matching its characteristics and qualities (Tables 3 and 4) with the land requirements for cocoa production (Table 1) following the rating of the characteristics (Table 2). The most limiting characteristic in a group determines performance of the group according to Liebig's Law of minimum and this was applied to the performance or suitability of a soil type.

The group of land qualities considered for evaluation include: climate (c), topography (t), drainage 
characteristics (w), soil physical characteristics (s) and soil chemical fertility (f). The soil fertility (f) was assessed using the soil reaction $(\mathrm{pH})$, level of macro and micro nutrients. The fertility requirements used by Fasina et al., (2007), Ritung et al., (2007) were modified using the critical soil conditions presented by Ibiremo et al., (2011). According to these authors, the soil critical fertility requirements for cocoa production are $0.9 \mathrm{~g} / \mathrm{kg} \mathrm{N}, 30.0 \mathrm{~g} / \mathrm{Kg} \mathrm{OC}, \mathrm{C} / \mathrm{N}$ ratio of 9 ; $\mathrm{pH}$ in water ranging from $58 ; 10.0 \mathrm{mg} / \mathrm{Kg} \mathrm{P}, 0.30 \mathrm{cmolc} / \mathrm{Kg} \mathrm{K}, 5 \mathrm{cmolc} / \mathrm{Kg} \mathrm{Ca}, 0.9 \mathrm{cmolc} / \mathrm{Kg} \mathrm{Mg}$, base saturation of $60 \%$ and $\mathrm{Ca} / \mathrm{Mg}$ ratio of 13 (Table 1). However, most of these data did not consider the role of the soil micronutrients in the performance of Cocoa. FFD (2011) indicated that Zinc deficiency can affect Cocoa seedling while Boron was only recommended at the rate of $30 \mathrm{~g}$ of Borax per plant in mature F3Amazon.

In computing the potential suitability for cocoa production, the fertility factors that can be amended by fertilizer additions and management practices were excluded. These factors include the level of available micro-nutrients (Cu and Boron), the levels of N, P, K and the organic matter content of the soil. However, the soil ECEC, percent base saturation and $\mathrm{pH}$ were considered.

The current suitability was computed linearly using index of current (actual) productivity (IPC) of Storie (1933)

$\mathrm{IP}_{\mathrm{C}}=\mathrm{A} \times \mathrm{B} / 100 \times \mathrm{S} / 100 \times \mathrm{C} / 100 \times \ldots . \mathrm{F} / 100$-.--- (i)

Where, $I P_{c}$ is index of current (actual) productivity, $A$ the overall least rating characteristic and $B, C \ldots$. are the least rating characteristic for each land quality group.

The potential suitability $\left(\mathrm{IP}_{\mathrm{P}}\right)$ was similarly computed using the potential index of productivity

The IPc and IPp were also computed using the square root model as stated below:

$I P c=A(S Q R T(B / 100 \times S / 100 \times C / 100 \times \ldots . . F / 100))$-.--(ii)

Where, $S Q R T$ is square root, $A$ the overall least characteristic rating and $B, C \ldots .$. were the least rating characteristic for each land quality group 
Table 1: Land Requirements for suitability evaluation of Cocoa

\begin{tabular}{|c|c|c|c|c|c|}
\hline Land Characteristics & S1 & S2 & S3 & N1 & N2 \\
\hline \multicolumn{6}{|l|}{ Climaate (C) } \\
\hline Annual Rainfall (mm) & 15002500 & 15001400 & & & \\
\hline 25003500 & 12001400 & & & & \\
\hline 35004500 & $<1200$ & $<100$ & & & \\
\hline Mean annual temperature $\left(0^{\circ} \mathrm{C}\right)$ & 2328 & 2835 & & & \\
\hline 2025 & 3538 & $>38$ & Any & & \\
\hline Length of Dry season (Months) & 12 & $2-3$ & 34 & $>4$ & Any \\
\hline Relative humidity (driest month) & 4065 & 3540 & & & \\
\hline 6575 & 3035 & & & & \\
\hline 7585 & $<30$ & & & & \\
\hline$>85$ & Any & & & & \\
\hline \multicolumn{6}{|l|}{ Topography (T) } \\
\hline Slope (\%) & $<8$ & 816 & $16-30$ & $>30$ & Any \\
\hline Erosion Hazard & Very low & Low moderate & Severe & Very Severe & Any \\
\hline \multicolumn{6}{|l|}{ Wetness (W) } \\
\hline Flooding & Fo & Fo & F1 & F1 & Any \\
\hline Drainage & WD & MD & ID & PD & VPD \\
\hline \multicolumn{6}{|l|}{ Soil Physical Properties (S) } \\
\hline Texture/Structure & C-60s to SC & $\mathrm{C}+60$ s to $\mathrm{SCL}$ & $C+60$ s to $L f s$ & $c S$ to Lfs & $\mathrm{Cm}$ to $\mathrm{cS}$ \\
\hline Coarse fragment $(\%)$ & $<15$ & 1535 & 3555 & $>55$ & Any \\
\hline Soil depth $(\mathrm{cm})$ & $>100$ & 75100 & 5075 & $<50$ & Any \\
\hline Surface stoniness (\%) & $<5$ & 515 & 1540 & $>40$ & - \\
\hline Rock- outcrop (\%) & $<5$ & 515 & 1525 & $>25$ & - \\
\hline \multicolumn{6}{|l|}{ Fertility Characteristics (F) } \\
\hline Apparent CEC (Cmolc/kg) & $>16$ & $12-16$ & 812 & $<8$ & - \\
\hline Base Saturation & $>60$ & 5035 & $<20$ & Any & - \\
\hline Organic matter $(\%$ OC $015 \mathrm{~cm})$ & $>3.0$ & 2.51 .5 & 1.50 .8 & 0.60 .8 & $<0.6$ \\
\hline $\mathrm{pH}$ in distilled water & 6.07 .0 & $7.0-7.6$ & & & \\
\hline 5.56 .0 & 5.54 .0 & & & & \\
\hline$>7.6$ & $<4.0$ & - & & & \\
\hline $\mathrm{Cu}(\mathrm{mg} / \mathrm{kg})$ & 410 & $2-4$ & 12 & $<1$ & \\
\hline Boron (mg/kg) & 0.51 .0 & 0.250 .5 & 0.140 .25 & $>3$ & \\
\hline
\end{tabular}


Table 2: $\quad$ Rating of limiting characteristics

\begin{tabular}{lll}
\hline Symbol & Definition & Land Index \\
\hline S1 & None & $70.0-100$ \\
S2 & Slight & $55.0-69.0$ \\
S3 & Moderate & $40.0-54.0$ \\
N1 & Severe & $20.0-39.0$ \\
N2 & Very severe & $0.00-19.0$ \\
\hline
\end{tabular}

\section{RESULTS}

\section{The Climate of Etung Local Government Area}

Climatic data for Etung Local Government Area (ETLGA) was not available. Therefore, data from Ikom meteorological station which was used by Grace et al., (2013) for the prediction of the impact of rainfall on cocoa production in this LGA is presented here.

The long term (30 years) mean total monthly rainfall from for lkom meteorological station indicated that the Local Government Area has typically single maximum rainfall pattern with August having the highest average monthly precipitation of about $615 \mathrm{~mm}$ while January had the least mean monthly precipitation of about $22 \mathrm{~mm}$. The annual total rainfall ranged from 1762.4 to $4381.1 \mathrm{~mm}$. The total number of rainy days averaged 161 days while the frequency of rainfall is highest in August with an average of 26 rainy days and least in December with about 3 rainy days. Etung Local Government Area has less than two dry months in a year. Similarly, the relative humidity is high throughout the year and ranged from $66.5 \%$ in February to $85 \%$ in August. Spot data collected by Cyprian et al., (2013) indicated that the total annual rainfall for Etung LGAin 2013 was $3123 \mathrm{~mm}$.

The trend of the rainfall showed that the total annual rainfall is increasing; indicating that both the mean monthly rainfall as well as the duration of the rainfall is expected to increase further from what is presently recorded. This has a very serious implication for the productivity of cocoa in the highly leached and extremely acid soils. The incidence of Black pod disease of cocoa is also likely to be on the increase.

The average annual temperature is about $29.80^{\circ} \mathrm{C}$ and ranged from $29.0^{\circ} \mathrm{C}$ in December to $31.750^{\circ} \mathrm{C}$ in March. Minimum temperature in the area ranged from $20^{\circ} \mathrm{C}$ to $24^{\circ} \mathrm{C}$, highest in November and lowest in between December and January, while the mean maximum temperature ranges between $28^{\circ} \mathrm{C}$ and $33^{\circ} \mathrm{C}$. The observed pattern of temperature regime is strongly influenced by the movement of the Inter-tropical Convergence Zone (ITCZ), wind direction and distance from the Atlantic Ocean. The ITCZ is responsible for the double temperature peak often experienced over the project area. The highest annual temperature reading occurs between March and April, 
while the lowest annual temperature usually occurs in August. Both the minimum and maximum temperature showed increasing trend. This may probably be in line with the general increase in global temperature. As such, the temperature of the area is expected to increase further.

\section{The Soil Physical and Morphological Characteristics}

The soils are deep, well drained with some of the profiles having gravel (quartz) at the second or third horizon (Table 3). The soils had sand particle size fraction that ranged from 24.4 to $87 \%$ and the sand content of the soils generally decreased with increase in soil depth. The silt content of the soil was lower than either the sand or clay content of the soils and ranged from 2.8 to $14.8 \%$ while the clay content of the soils ranged from 9.6 to $68.8 \%$. In all the pedon, there was increase in the clay content with increase in soil depth. However, only four pedons (ELG1, ELG5, ELG7 and ELG8) had clay bulge in the B horizon.

The texture of the soils ranged from loamy sand or sandy loam in the surface horizons to clay or heavy clay in the subsurface horizons. 
Ajiboye, Jaiyeoba, Olaniyan and Olaiya

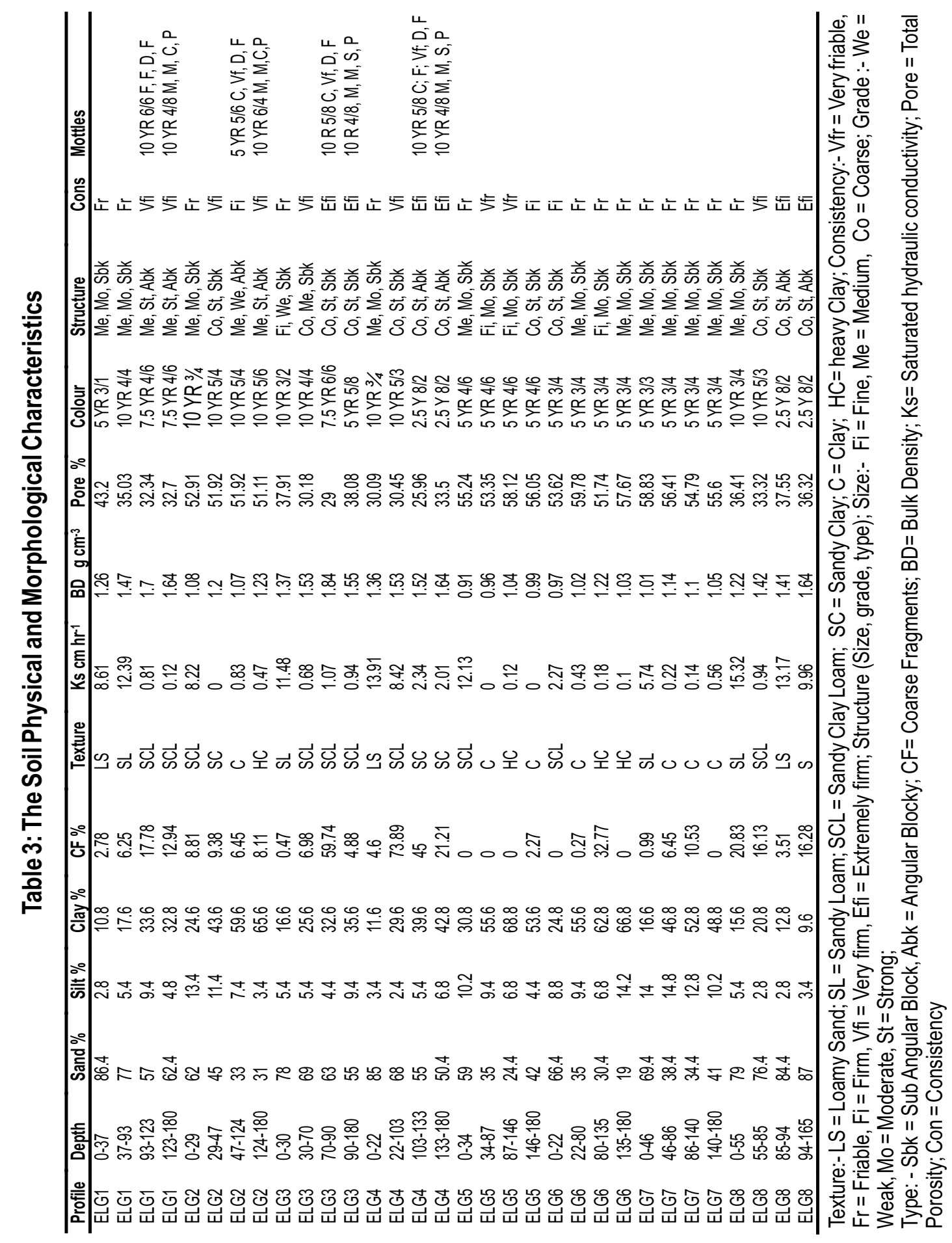


Pedon ELG5 had no coarse fragment (gravel) while pedons ELG3 and ELG4 had coarse fragment in excess of $50 \%(\mathrm{w} / \mathrm{w})$ in the $B$ horizon but all the other pedons had coarse fragment that ranged from 0 and $32.77 \%$. The saturated hydraulic conductivity of the soils ranged from low $\left(0 \mathrm{~cm} \mathrm{hr}^{-1}\right)$ to moderate $\left(15.32 \mathrm{hr}^{-1}\right)$; lower in horizons having clay or heavy clay texture and higher in the horizons having loamy sand or sandy loam texture. The bulk density of these soils ranged from low $\left(0.91 \mathrm{~g} \mathrm{~cm}^{-3}\right)$ to moderate $\left(1.84 \mathrm{~g} \mathrm{~cm}^{-3}\right)$. The surface horizons of the pedons had the lowest bulk density. The total porosity was moderate in all the pedons and ranged from 25.96 to $59.78 \%$.

In terms of colour, the soils can be grouped into two (mapping units) units because of the contrasting colour hue in the surface and subsurface horizons. Pedons ELG1, ELG2, ELG3, ELG4 and ELG8 had soil colour hue of $10 \mathrm{YR}$ in the surface horizons with colour values that ranged from 3 to 5 while the colour chroma ranged from 1 to 6 . Thus, the surface horizons of these pedon had colour variation between yellowish brown and dark gray. The subsurface horizons of these pedon had different shades of colour including 2.5Y, 10YR and 7.5YR. The subsurface colour ranged from white $(2.5 \mathrm{Y}$ $8 / 2$ ) to reddish yellow (7.5YR 6/6). Most of the soil in this group had few many, very fine medium, diffuse sharp and faint prominent mottles. The mottles colour ranged from $10 \mathrm{YR}$ to $10 \mathrm{R}$ with colour value that ranged from 4 to 6 while the chroma ranged from 4 to 8 . The soils in this group are generally termed as the "white soils" by the local farmers in this area because the colour looks whitish when observed at a distance. Pedons ELG5, ELG6 and ELG7 had different colour matrix with soil colour hue of $5 \mathrm{YR}$ in the surface horizons with colour values that ranged from 3 to 4 while the colour chroma ranged from 4 to 6 . These pedons had surface colour that ranged from dark reddish brown (5YR 3/3) to yellowish red (5YR 4/6). Contrary to the "white soils", the subsurface horizons of the soils in this group had colour hue of 5YR, colour value that ranged from 3 to 4 and colour chroma which ranged from 4 to 6 . As such, the subsurface colour ranged from dark reddish brown to yellowish red. The soils in this group are termed "red" soils by the local farmers and are preferred for cocoa production than the "white soils".

The soil had structures that varied from fine-sub-angular-blocky (fsbk) in the surface horizon to coarse-sub angular-blocky (csbk) in the sub soil. The consistency of the soils ranged from very friable in the surface to firm in the subsurface.

The soils had low- moderate saturated hydraulic conductivity $\left(0-15.32 \mathrm{~cm} \mathrm{~h}^{-1}\right)$, moderate bulk density (0.91 1.84) and low moderate total porosity (25.96 59.78\%). There was a general decrease in the Ks with increasing depth from the surface. Conversely, there was a general increase in the bulk density with increase in soil depth.

\section{The Soil's Chemical Properties}

The soil reaction ranged from extremely acid to moderately acid (4.20 6.65 in distilled water) and from extremely acid to very strongly acid $(3.454 .90 \mathrm{in} \mathrm{KCl}$ ). The organic carbon content of the soil ranged from $3.59 \%$ in the surface horizon to $0.04 \%$ in the subsurface horizon. Generally the organic carbon content of the soil decreased expectedly with increase in soil depth. Like in most Nigerian soils, the total nitrogen contents of the soils were very low $(<0.10 \%)$ in the subsurface horizons but slightly higher $(0.11-0.267 \%)$ in the surface horizons (Table 4). The carbon nitrogen ratio (C: $N)$ of the soils ranged from1.39 to13.47 and generally decreased with increase in soil depth. The available phosphorus content of the soils (Bray 1 ) ranged from very 


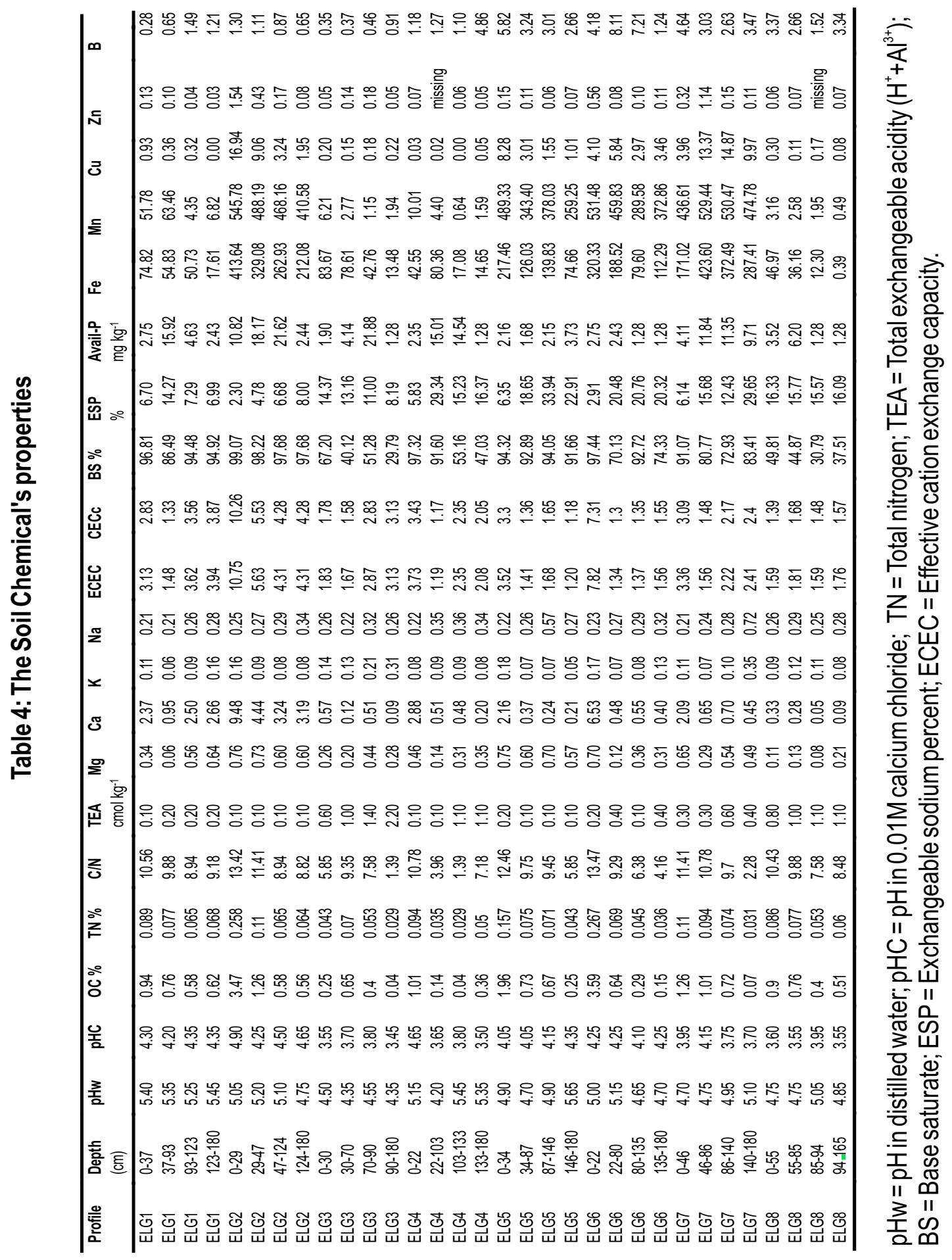


low $\left(1.28 \mathrm{mg} \mathrm{kg}^{-1}\right)$ to high $\left(21.88 \mathrm{mg} \mathrm{kg}^{-1}\right)$. The total exchangeable acidity $\left(\mathrm{H}^{+}+\mathrm{Al}^{3+}\right)$ of the soil were low high and ranged from 0.10 to $2.20 \mathrm{cmol} \mathrm{kg}^{-1}$. The exchange sites of the soils were dominated by $\mathrm{Ca}^{2+}$ which hand values that ranged from $0.05 \mathrm{cmol} \mathrm{kg}^{-1}$ in the subsurface horizons to $9.48 \mathrm{cmol} \mathrm{kg}^{-1}$ in the surface horizons. The values of $\mathrm{Mg}^{2+}$ in the soils also ranged from 0.08 to $0.76 \mathrm{cmol} \mathrm{kg}^{-1}$ while the values of $\mathrm{K}^{+}$in the soils ranged from 0.07 to $0.16 \mathrm{cmol} \mathrm{kg}^{-1}$. The $\mathrm{Na}^{+}$ranged from 0.21 to 0.57 $\mathrm{cmol} \mathrm{kg}^{-1}$ and the effective cation exchange capacity (ECEC) ranged from 1.67 to $10.75 \mathrm{cmol} \mathrm{kg}^{-1}$. The exchangeable bases ( $\mathrm{Ca}, \mathrm{Mg}, \mathrm{K}$ and $\mathrm{Na}$ ) and ECEC of these soils were very low, generally below the critical requirements for Cocoa production. However, the levels of available micronutrients ( $\mathrm{Fe}, \mathrm{Mn}, \mathrm{Cu}$ and $\mathrm{B}$ ) are very high. The values of iron content of the soils ranged from 12.30 to $413.64 \mathrm{mg} \mathrm{kg}^{-1}$ while the manganese $(\mathrm{Mn})$ content ranged from 0.49 to $531.48 \mathrm{mg} \mathrm{kg}^{-1}$. These two elements had very high values which were considered as toxic in some of the pedons. However, the copper (Cu) content of the soils were moderate to high and ranged from 0.02 to 16.94 $\mathrm{mg} \mathrm{kg}^{-1}$ and the values were generally highest in the surface horizons. The zinc $(\mathrm{Zn})$ content of the soils were very low and most cases fell below the critical requirements for cocoa production and ranged from 0.05 to $1.54 \mathrm{mg} \mathrm{kg}^{-1}$. Similarly, the boron status of the soil ranged from $0.28 \mathrm{mg} \mathrm{kg}^{-1}$ (very low) to $8.11 \mathrm{mg} \mathrm{kg}^{-1}$ (very high).

\section{Land Evaluation}

The climate conditions of Etung Local Government Area (ELG) are rated as S2, S1 and S1 in term of rainfall, relative humidity and length of dry season respectively (Table 5). This is because the mean annual rainfall which ranged from $29003000 \mathrm{~mm}$ is considered to be excessive (Fasina et al., 2007). The slope, drainage and flooding conditions of all the pedons are rated as S1. The average soil rooting depth which is greater than $150 \mathrm{~cm}$ in all the pedons is also rated as S1. Similarly, in term of surface stoniness presence of rock outcrop, all the pedons are rated as $\$ 1$. The textural and structural classes of the soils which include sandy loam in the surface horizons to sandy clay loam, sandy clay or clay in the subsurface horizons is rate as S1 for pedons ELG2, ELG5ELG6 and ELG7 and $S 2$ in pedon ELG3 and ELG4 while pedons ELG1 and ELG8 are rated as S3.

Apart from the base saturation which was high and rated as S1 in pedons ELG1 ELG7 and S2 in pedon ELG8, all the other fertility requirements considered for this evaluation were sub-optima and were rate different between $\mathrm{S} 2$ and $\mathrm{S} 3$. The most limiting fertility parameter is the apparent cation exchange capacity which is rated as $\mathrm{N} 2$ in all the pedons. Also the $\mathrm{pH}$ of the soil was low and qualifies all the pedon as S3 soils. In some of the pedons, the level of boron and copper were also low and rated either as $\mathrm{N} 1$ or $\mathrm{N} 2$.

Cumulatively, the aggregate actual suitability class of all the pedons either by the linear parametric or square root model is N2, suggesting that the soils are not currently suitable for cocoa production (Tables 5 and 6). However, with adequate application of the appropriate type of fertilizers, the productivity of the soils could be improved. Thus, the potential suitability which is a reflection of what is expected after good soil fertility management is marginal (S3) for all the pedons except pedons ELG1 and ELG8 where the soil will still remain as unsuitable (N1) after the amendment of the fertility status of the soil (Tables 5 and 6 ). The only difference in the results computed by the two models 
(Linear and Square root models) is that while the linear model rated pedons ELG1 and ELG8 as potentially unsuitable (N1), the square root model rated these pedons as potentially marginally suitable (S3). Thus apart from the fertility status of these soils, there are other factors, especially, the relative humidity of the driest month and some other soil physical properties (soil structure and texture) that need amendment before the productive capacity of the soils can become highly suitable for cocoa production.

Table 5: Land Suitability ratings of the soils of Etung Local Government Area for cocoa production

\begin{tabular}{|c|c|c|c|c|c|c|c|c|}
\hline Land Characteristics & ELG1 & ELG2 & ELG3 & ELG4 & ELG5 & ELG6 & ELG7 & ELG8 \\
\hline \multicolumn{9}{|l|}{ Climaate (C) } \\
\hline Annual Rainfall (mm) & 62 (S2) & 62 (S2) & 62 (S2) & $62(\mathrm{~S} 2)$ & 62 (S2) & 62 (S2) & 62 (S2) & $62(\mathrm{~S} 2)$ \\
\hline Mean annual temperature $\left(0^{\circ} \mathrm{C}\right)$ & 100 (S1) & $100(S 1)$ & $100(S 1)$ & $100(S 1)$ & $100(S 1)$ & $100(S 1)$ & $100(S 1)$ & $100($ (S1) \\
\hline Length of Dry season(Months) & $100(\mathrm{~S} 1)$ & 100 (S1) & 100 (S1) & $100(\mathrm{~S} 1)$ & $100(\mathrm{~S} 1)$ & 100 (S1) & $100(S 1)$ & $100(S 1)$ \\
\hline Relative humidity (driest month) & $45(\mathrm{~S} 3)$ & $45($ (S3) & $45(\mathrm{~S} 3)$ & $45(\mathrm{S3})$ & $45(\mathrm{~S} 3)$ & $45(\mathrm{~S} 3)$ & $45(\mathrm{~S} 3)$ & $45(\mathrm{S3})$ \\
\hline \multicolumn{9}{|c|}{ Topography (T) } \\
\hline Slope $(\%)$ & $100(S 1)$ & $100(S 1)$ & $100(S 1)$ & 100 (S1) & 100 (S1) & 100 (S1) & $100(S 1)$ & 100 (S1) \\
\hline Erosion Hazard & 100 (S1) & $100(S 1)$ & $100(S 1)$ & $100(S 1)$ & $100(S 1)$ & $100(S 1)$ & $100(S 1)$ & $100(S 1)$ \\
\hline \multicolumn{9}{|l|}{ Wetness (W) } \\
\hline Flooding & $100(S 1)$ & $100(S 1)$ & $100(S 1)$ & $100(S 1)$ & $100(S 1)$ & $100(S 1)$ & $100(S 1)$ & $100(S 1)$ \\
\hline Drainage & 100 (S1) & $100(S 1)$ & $100(S 1)$ & $100(S 1)$ & $100(\mathrm{~S} 1)$ & $100(\mathrm{~S} 1)$ & $100(S 1)$ & $100(S 1)$ \\
\hline \multicolumn{9}{|l|}{ Soil Physical Properties (S) } \\
\hline Texture/Structure & 54 (S3) & $100(S 1)$ & 69 (S2) & 69 (S2) & $100(S 1)$ & $100(\mathrm{~S} 1)$ & $100(S 1)$ & $50(S 3)$ \\
\hline Coarse fragment (\%) & 100 (S1) & 100 (S1) & 64 (S2) & 40 (S3) & 100 (S1) & 100 (S1) & 100 (S1) & 100 (S1) \\
\hline Soil depth (cm) & 100 (S1) & 100 (S1) & 100 (S1) & 100 (S1) & 100 (S1) & 100 (S1) & 100 (S1) & 100 (S1) \\
\hline Surface stoniness (\%) & 100 (S1) & 100 (S1) & 100 (S1) & 100 (S1) & 100 (S1) & 100 (S1) & 100 (S1) & $45(\mathrm{~S} 3)$ \\
\hline Rock- outcrop (\%) & 100 (S1) & 100 (S1) & 100 (S1) & $100(S 1)$ & 100 (S1) & 100 (S1) & 100 (S1) & $100(S 1)$ \\
\hline \multicolumn{9}{|l|}{ Fertility Characteristics (F) } \\
\hline Apparent CEC (Cmolc/kg) & 19 (N2) & 19 (N2) & 19 (N2) & 19 (N2) & 19 (N2) & 19 (N2) & 19 (N2) & 19 (N2) \\
\hline Base Saturation & $100(S 1)$ & $100(S 1)$ & $100(S 1)$ & $100(S 1)$ & $100(S 1)$ & 100 (S1) & $100(S 1)$ & 60 (S2) \\
\hline Organic matter (\% OC 0 - 1c5m) & $40(S 3)$ & 100 (S1) & 10 (N2) & $43(S 3)$ & $62(S 2)$ & $100(\mathrm{~S} 1)$ & $45(S 3)$ & 40 (S3) \\
\hline pH in distilled water & $54(\mathrm{~S})$ & $50(S 3)$ & $45(\mathrm{~S})$ & $51(\$ 3)$ & $50(\mathrm{~S})$ & $48(S 3)$ & $48(S 3)$ & $49(\mathrm{~S} 3)$ \\
\hline $\mathrm{Cu}(\mathrm{mg} / \mathrm{kg})$ & 20 (N2) & $100(S 1)$ & 15 (N2) & 10 (N2) & 60 (\$2) & 75 (S1) & $100(S 1)$ & 10 (N2) \\
\hline Boron (mg/kg) & $100(S 1)$ & 100 (S1) & 100 (S1) & 39 (N1) & 39 (N1) & 39 (N1) & 39 (N1) & 39 (N1) \\
\hline Actual Suitability (Linear) & 4.52 (N2) & $8.55(\mathrm{~N} 2)$ & 2.88(N2) & $1.80(\mathrm{~N} 2)$ & 8.55 (N2) & 8.55 (N2) & $8.55(\mathrm{~N} 2)$ & $4.28(\mathrm{~N} 2)$ \\
\hline Actual Suitability (Square root) & $9.37(\mathrm{~N} 2)$ & 12.75 (N2) & 5.37 (N2) & $4.24(\mathrm{~N} 2)$ & $12.75(\mathrm{~N} 2)$ & $12.75(\mathrm{~N} 2)$ & $12.75(\mathrm{~N} 2)$ & $9.01(\mathrm{~N} 2)$ \\
\hline Potential Suitability (Linear) & 24.3(N1) & $45(S 3)$ & $28.80(S 3)$ & 18.00 (N1) & $45(S 3)$ & $45(S 3)$ & $45(\$ 3)$ & 22.25 (N1) \\
\hline Potential Suitability (Square root) & $33.07(\mathrm{~S} 3)$ & $45(S 3)$ & $36.00(S 3)$ & 13.41 (N1) & $45(S 3)$ & $45(S 3)$ & $45(\mathrm{~S} 3)$ & $31.82(\mathrm{~S} 3)$ \\
\hline
\end{tabular}


Table 6: Qualitative land suitability classes for the different land indices

\begin{tabular}{lll}
\hline Symbol & Definition & Land Index \\
\hline S1 & Highly suitable & 75.0100 \\
S2 & Moderately suitable & 50.075 .0 \\
S3 & Marginally suitable & 25.050 .0 \\
N1 & Presently not suitable & 12.525 .0 \\
N2 & Permanently not suitable & $0.00-12.50$ \\
\hline
\end{tabular}

\section{DISCUSSION}

The long term average annual rainfall ranging from $25003500 \mathrm{~mm}$ is counter- productive (Cyprian et al., 2013; Grace et al., 2013). This high rainfall is probably the cause of excessive leaching of soluble bases leading to the low pH observed in these soils. According to the report of several authors, high rainfall results in the leaching of soluble nutrient elements including $\mathrm{K}, \mathrm{Na}, \mathrm{Mg}, \mathrm{K}$ and nitrogen (Onweremadu and Uhuegbu, 2007; Yasin et al., 2010). Apart from its effect on soil nutrient status, high rainfall was reported to be negatively correlated with the incidence of Black-pod disease of cocoa while high relative humidity within cocoa plantation was implicated in the high incidence of black pod disease of cocoa caused by Phythophtora palmivora (Lawal and Emaku, 2007). The low $\mathrm{pH}$ of the soils has implication for the management of applied phosphorus fertilizers. At $\mathrm{pH}$ below 5.5, it has been reported that most of the applied $\mathrm{P}$ are fixed by iron and aluminum oxides (Agbenin, 2003; Igwe et al., 2005). The application of copper-based fungicides for the control of has also been reported to be the major cause of the high Cu status of the surface horizons in tree crop plantation soils (Brun et al., 1998; Gallagher et al., 2001; Van Zwieten et al., 2004). Recommending fertilizer and soil management practices for these soils requires a careful study of the fertilizer types, rates and method of application that will result in the optima performance of the soils.

\section{CONCLUSIONAND RECOMMENDATIONS}

The nutrient holding capacities of these soils as indicated by the CEC were very low and the rainfall both in amount and intensity were very high in Etung Local Government Area. These two factors combined with the low $\mathrm{pH}$, high $\mathrm{Fe}$ and $\mathrm{Mn}$ contents of the soils call for caution in the type and method of fertilizer application on the soil. Fertilizers having appreciable amount of $\mathrm{CaO}$ and $\mathrm{MgO}$ in addition to $\mathrm{N}, \mathrm{P}$ and $\mathrm{K}$ will be of uttermost benefit to cocoa production in this Local Government. Therefore, the recommended rate of N, P, K for low fertility soils (FFD, 2011) could be adopted using non-acidifying fertilizer sources with quantities of $\mathrm{MgO}$ and $\mathrm{CaO}$ that will be sufficient to raise the $\mathrm{pH}$ of the soils above 5.5 and good supply of $\mathrm{Ca}$ and $\mathrm{Mg}$. From several studies on soil fertility management in high rainfall and acidic soils, the use of organic manures and partially acidulated 
phosphate rocks as fertilizer sources is highly recommended. In terms of application of the mineral fertilizers, split application is recommended to prevent leaching that may result from the high rainfall amount and intensity in this region.

\section{REFERENCES}

Adeyina A.O., Annongu A.A. and Awe O. (2010). "Effects of Cocoa Bean Shell on the Performance, Blood Indices and Organ Characteristics of Cockerels. "Agrosearch 10 (1-2): 11-19.

Agbenin J .O. (2003)."Extractable Iron and Aluminum Effects on Phosphate Sorption in Savanna Alfisol."Soil Sci. Soc.Am. J. 67:589-593.

Ajiboye G. A., Alabi K. O, Adesodun J. K. and Aiboni, V. U. (2011). "Classification and Suitability Evaluation of the soils of a toposequence at Odeda, Ogun State for the production of rice (Oryza sativa)." Nigerian Journal of Soil Science21 (2):142-155.

'Anderson J. M. and Ingram J. S. I. (1993). "Tropical Soil Biology and Soil Fertility: A Handbook of Methods." Wallingford, UK:.C.A.B International.

Brun L. A., Maillet J., Richarte J., Herrmann P. and Remy J. C. (1998). "Relationships between Extractable Copper, Soil Properties and Copper Uptake by Wild Plants in Vineyard Soils."Environmental Pollution. 102: 151161

Day P. R. (1982). "Particle Fractionation and Particle-Size Analysis." In: Methods of Soil Analysis Part 2, Chemical and Microbiological Properties. (ed (s) Page A.L., Miller R.H. and Keeney D.R. ).545-567. Madison, WI.Soil Science Society of American, Inc.

FAO.(2007). "Methods of Analysis for Soils of Arid and Semi-Arid Regions." (ed (s) Bashour I. L. and SayoghA.H.). 128pp..

Fasina A. S., Omotoso S. O., Shittu O. S and Adenikinju A. P. (2007). "Properties, Classification and Suitability Evaluation of Cocoa Soils of South- Western Nigeria."American-Eurasian. J. Agric and Environ Sci.. 2(3): 312-317.

FFD (Federal Fertilizer Department). (2011). "Fertilizer Use and Management Practices for Crop Production in Nigeria." (ed (s) Chude V. O., Olayiwola S. O., Osho A. O. and Daudu C. K.). $4^{\text {th }}$ Edition. Abuja, Nigeria. Federal Ministry of Agriculture and Rural Development.ISSN 115-554X;

Folayan J.A, Daramola G. A and Oguntade A.E. (2006). "Structure and Performance Evaluation of Cocoa Marketing Institutions in South-Western Nigeria: An Economic Analysis." Journal of Food, Agriculture and Environment. 4 (2): 123-128.

Food and Fertilizer Technology Centre. (2001). "Micronutrient Deficiencies of Crops in Asia." Report on International Workshop on Micronutrients in Crop ProductionHeld at National Taiwan University, Taipei, Taiwan ROC, November 8-13, 1999.5F.14 Wenchow St., Taipei 10616 Taiwan R.O.C.

Gallagher D.L., Johnston K. M. and Dietrich A. M.(2001). "Fate and Transport of Copper-based Crop Protectants in Plasticulture Runoff and the Impact of Sedimentation as a Best Management Practice."Water Research. 35: 29842994 
Hamzat, R.A., Olaiya, A.O.,Sanusi, R.Aand Adedeji, A.R. (2006)."State of Cocoa Growing, Quality and Research in Nigeria" Need for intervention." ISBN: $9780732599.52 \mathrm{pp}$.

Jimoh A. (2005). "The malaria burden and agricultural output in Nigeria."Agrosearch Journal. 7(2): 43-50

Ibiremo O. S., Daniel M.A., Iremiren G. O. and Fagbola O. (2011)."Soil Fertility Evaluation for Cocoa Production in Southeastern Adamawa State, Nigeria."World Journal of Agricultural Sciences. 7 (2): 218-223.

Cyprian A. E., Margaret A. Y., Asuquo E. O. and Francis E. B. (2014). "Rural Peoples' Perception to Climate Variability/Change in Cross River State-Nigeria."Journal of Sustainable Development. 7(2): 25-36.

Grace N.O., Afangideh I. A. and Linus B. O. (2013)."Impact of Rainfall Regime on Cocoa Production in Etung Local Government Area, Cross River State Nigeria."Asian Journal of Agriculture and Food Science. 1(5): 243-251.

ICCO.(2006). "Annual Report 2005/2006."International Cocoa Organization.http://www.icco.org/about-us/international-cocoa-agreements/cat view/1annual-report/23-icco-annual-report-in-english.html

Igwe C. A., Zarei M. and Stahr K. (2005). "Mineral and Elemental Distribution in Soils Formed on the River Niger Floodplain Eastern Nigeria." Aust. J. Soil Res. 43: 147-158

Iremiren G. O., Oduwole O. O., Obatolu B. O., Aigbekaen E., Sanusi R. A., Shittu T. R., Emaku L. E., Ibiremo O. S., Aikpokpodion P., Agbeniyi S. O., Ndubuaku T. C. N., Adeogun S. and Olaiya A. (2012). "Cocoa Production Survey in Nigeria." Report published by Cocoa Research Institute of Nigeria. ISBN : 9789785065664 . Pages: 84.

Lawal J. O. and Emaku L. A. (2007). "Evaluation of the Effects of Climatic Changes on Cocoa Production in Nigeria: Cocoa Research Institute of Nigeria (CRIN) as a case study." Afri. Crop Sci. Conf. Proc. 8: 423426.

McLean E. O. (1982). "Soil pH and Lime Requirement." In: Methods of Soil Analysis Part 2: Chemical and Microbiological Properties. (ed (s) Page A. L., Miller R. H. and Keeney D.R.). 199-224. 2nd Edn. New York, USA. ASA and SSSA.

Murphy J. and Riley J. P. (1962)."A Modified Single Solution Method for the Determination of Phosphate in Natural Waters."Anal Chemical Acta. 27:3136.

Nelson D. W. and Sommers L. E. (1975)."A Rapid and Accurate Method of Estimating Organic Carbon in soil."Proc. of Indiana Academy of Science. 84: 456-462

Onweremadu E. U and Uhuegbu A. N. (2007)."Pedogenesis of Calcium in Degraded Tropical Rangeland soils." Journal of American Science. 3(2): 23-29

Reynolds W. D. (1993).“Saturated Hydraulic Conductivity: Laboratory measurement.” In: Soil Sampling and methods of analysis. (ed. Carter M. R. ). 589598. Lewis Publishers, Boca Raton, FL. Canadian Society of Soil Science. 
Ritung S., Wahyunto Agus F. and Hidayat H. (2007). "Land Suitability Evaluation with a case map of Aceh Barat District".Indonesian Soil Research Institute and World Agroforestry Centre, Bogor, Indonesia:

Storie R. E. (1933). "An Index for Rating the Agricultural Value of Soils."Bulletin - California Agricultural Experiment Station 556, University of California Agricultural Experiment Station, Berkley, CA.

Uddoh T. B. (2008). "Soil Texture and fertility constraint in land suitability for Oil-Palm cultivation in a humid tropical climate of Akwa Ibom State, Nigeria."Nigerian Journal of Soil Science. 18: $175-182$

Van Zwieten L., Rust J., Kingston T., Merrington G. and Morris S. (2004). "Influence of Copper Fungicide Residues on Occurrence of Earthworms in avocado orchard Soils". The Science of the Total Environment. 329: 2941

Yasin, S., Junaidi A., Wahyudi E., Herlena S. and Darmawan K. K. (2010)."Changes of Soil Properties on Various Ages of Rubber Trees in Dhamasraya, West Sumatra, Indonesia." J Trop Soils. 15(3):221-227. 